IZA DP No. 10142

How Do Users Value a Network Expansion?

Evidence from the Public Transit System in Singapore

Eric Fesselmeyer

Haoming Liu

August 2016

Forschungsinstitut

zur Zukunft der Arbeit

Institute for the Study

of Labor 


\title{
How Do Users Value a Network Expansion? Evidence from the Public Transit System in Singapore
}

\author{
Eric Fesselmeyer \\ National University of Singapore \\ Haoming Liu \\ National University of Singapore \\ and IZA \\ Discussion Paper No. 10142 \\ August 2016 \\ IZA \\ P.O. Box 7240 \\ 53072 Bonn \\ Germany \\ Phone: +49-228-3894-0 \\ Fax: +49-228-3894-180 \\ E-mail: iza@iza.org
}

\begin{abstract}
Any opinions expressed here are those of the author(s) and not those of IZA. Research published in this series may include views on policy, but the institute itself takes no institutional policy positions. The IZA research network is committed to the IZA Guiding Principles of Research Integrity.

The Institute for the Study of Labor (IZA) in Bonn is a local and virtual international research center and a place of communication between science, politics and business. IZA is an independent nonprofit organization supported by Deutsche Post Foundation. The center is associated with the University of Bonn and offers a stimulating research environment through its international network, workshops and conferences, data service, project support, research visits and doctoral program. IZA engages in (i) original and internationally competitive research in all fields of labor economics, (ii) development of policy concepts, and (iii) dissemination of research results and concepts to the interested public.
\end{abstract}

IZA Discussion Papers often represent preliminary work and are circulated to encourage discussion. Citation of such a paper should account for its provisional character. A revised version may be available directly from the author. 
IZA Discussion Paper No. 10142

August 2016

\section{ABSTRACT \\ How Do Users Value a Network Expansion? Evidence from the Public Transit System in Singapore}

We estimate the network externality of a public transit system by examining the effects of its expansion on the housing market. Our results show that a major expansion of Singapore's Mass Rapid Transit (MRT) system increased the price of apartments within $0.5 \mathrm{~km}$ of a preexpansion station by $1.6 \%$ to $2.1 \%$ relative to apartments that were further away from a station. Evaluated at the mean housing price, the expansion increased the value of preconnected apartments by at least $\mathbf{S} \$ 386$ million, which is equivalent to about $8 \%$ of the estimated $\mathrm{S} \$ 5$ billion cost of the expansion.

JEL Classification: H4, R21, R42, H23

Keywords: public transportation, housing, network effects

Corresponding author:

Haoming Liu

Department of Economics

National University of Singapore

1 Arts Link

Singapore 117570

E-mail: ecsliuhm@nus.edu.sg 


\section{Introduction}

With ever increasing connectivity, understanding the network economy has become important. While it has been well established theoretically that the value of a network increases with its size (Katz and Shapiro, 1985; Liebowitz and Margolis, 1994), empirical studies on this issue are still scant. Moreover, to the best of our knowledge, there exists no empirical study that has examined network effects in the context of a public transit system. Similar to the expansion of a network of automated teller machines examined by Saloner and Shepard (1995) and the adoption of the automated clearing house electronic payment systems examined by Gowrisankaran and Stavins (2004), 1 $^{1}$ an expansion of a public transit system benefits not only new users but also existing users.

Public transit systems provide many benefits such as faster travel between locations, reduced traffic congestion, and easier assess to workplaces and shops Baum-Snow and Kahn, 2000). A reduction in traffic congestion reduces auto emissions, hence improving air quality, and easier access to employment centers raises labor force participation, particularly for women (Black et al., 2014). Public transit systems have even been shown to reduce drunk driving (Jackson and Owens, 2011). However, public transit systems are very costly. For example, the Los Angeles Red Line alone cost $\$ 4.7$ billion to build (Nelson, 2015). As such, accurate measures of the net benefits of public transportation are necessary to help guide policymakers considering such huge investments.

Traditionally, economists have attempted to measure the gross benefits of public transportation by comparing the values of housing near the location of new stations before and after construction (Dewees, 1976; Voith, 1991; McDonald and Osuji, 1995; Baum-Snow and Kahn, 2000; Bowes and Ihlanfeldt, 2001; McMillen and McDonald, 2004; Gibbons and

${ }^{1}$ Some early studies of network effects include Gandal (1994) and Brynjolfsson and Kemerer (1996). 
Machin, 2005) 2 $^{2}$ This approach is motivated by the simple logic that the benefits of public transportation are capitalized into the price of housing near new transit stations as people are willing to pay more for these now more desirable units. However, without including the potential gains to households who already have access to the existing system, the benefits documented in previous studies could considerably underestimate the total benefits of the network expansion.

This paper examines the impact of an expansion of a public transit system on the value of housing that was connected to the system prior to the expansion. (This housing will be referred to as "pre-connected" housing hereafter). Finding a positive effect on the price of pre-connected housing would suggest that the benefits of public transportation systems have been underestimated in the existing literature. Moreover, by focusing on pre-connected housing in built-up areas in which amenities and the housing supply were stable, our approach provides a cleaner identification of the direct benefit that public transportation provides, namely making travel between locations faster and easier. In contrast, the approach used in previous studies have difficulty establishing a causal link between changes in housing value and the accessibility to public transit system because, as pointed out by Bowes and Ihlanfeldt (2001), changes in house prices could be due either to changes in connectivity, or to changes in the ambient environment around the new stations, such as the addition of new retail establishments and an increase in crime and noise. Local housing supply might also respond to an expansion of the transit system if property developers target these newly connected locations for new construction.

We consider a major expansion of the local commuter rail system in Singapore, the Mass Rapid Transit (MRT) system. The construction of the North East Line increased

\footnotetext{
${ }^{2}$ Differences in house values has also been used to evaluate the benefits of other public investments, such as environmental cleanup programs (Greenstone and Gallagher, 2008; Bajari et al., 2012).
} 
the number of MRT stations from 51 in 2002 to 65 in 2003 and increased total rail length from $89.4 \mathrm{~km}$ to $109.4 \mathrm{~km}$, a jump of more than 20\%. The expansion made it possible for people to ride the MRT to, among other places, two of the most popular retail and commercial areas in Singapore: HarbourFront, which contains a cruise ship terminal and VivoCity, Singapore's biggest mall, and China Town and China Square which contains $3.8 \%$ of all retail space and $5.1 \%$ of all office space in Singapore.

To estimate the benefits of the expansion on pre-connected housing we use a differencein-differences approach with rich transaction data of apartment sales provided by Singapore's public housing authority, the Housing Development Board (HDB). As we explain in detail below, while HDB allocates newly built public housing according to a set of rules and regulations, we use transaction data from the resales market, which is competitive, active, and relatively free of regulation.

Our results show that the addition of the North East Line raised the value of a preconnected apartment by 1.6 to $2.1 \%$, or around $\$ \$ 4,000$ to $\mathrm{S} \$ 5,000$ when evaluated at the mean transaction price of $\mathrm{S} \$ 245,270$ (about US\$180,000 dollars) $!^{3}$ To get a sense of the size of this effect in aggregate, consider that in 2002 there were about 428,481 housing units located in the 13 Singapore "towns" we include in the analysis, and that pre-connected housing makes up between $20 \%$ to $40 \%$ of our sample, depending on the definition of connectivity. Assuming, for illustration, that $30 \%$ of units were affected, then our estimates imply that the expansion of the MRT added a total of S\$386 million to the value of pre-connected housing, equivalent to about $8 \%$ of the estimated $\mathrm{S} \$ 5$ billion cost of constructing the new line (Leong Chan Teik, 1996). Keep in mind that this percentage does not include the direct effect of the expansion on newly connected housing. Our findings suggest that the benefits realized by households living in pre-connected apartments

\footnotetext{
${ }^{3}$ The median monthly salary in January 2000 was $\mathbf{S} \$ 3,173$.
} 
constitutes a considerable fraction of the gains provided by mass transit systems and should be included in cost-benefit analyses evaluating these types of investments, which is not the current practice. Our results also show the importance of network externalities in public transportation networks.

\section{Institutional background and data}

\subsection{Background}

Singapore is a city-state of 719 square $\mathrm{km}$ with a population of 5.5 million, of which 3.9 million are citizens or residents, and a population density of 7,800 persons per square $\mathrm{km}$ (about 20,000 persons per square mile). Per capita GDP is $\mathbf{S} \$ 72,000$ (US\$53,000), and home ownership among households headed by a citizen or permanent resident is a very high 91\% (Singapore Department of Statistics, 2015).

The vast majority of Singapore's population lives in apartments in high-rise buildings developed by Singapore's public housing authority, the Housing and Development Board (HDB). HDB is a statutory board established in 1960 when Singapore was suffering a severe housing crisis due to overcrowding, slums, squatter settlements, and unhygienic conditions. HDB was tasked with providing safe, modern, and affordable housing on a large scale (Yueng, 1973). HDB was remarkably successful and nearly 90\% of Singaporeans currently live in an HDB apartment $4^{4}$

To alleviate the housing crisis, the newly created HDB planned to build 147,000 units in its first decade with another 100,000 units to come by 1975 (Yueng, 1973). To meet these goals and to keep costs low, early HDB apartments were designed to be simple, stan-

\footnotetext{
${ }^{4}$ According to the HDB Annual Report 2014/15, the total stock of HDB dwelling units in 2015 was 968,856 . Most of the remaining population live in apartments in high-rise buildings built by private developers.
} 
dardized, utilitarian, and capable of being built quickly. Initially, apartments were either one, two, or three rooms, and came in three different models: "emergency", "standard," and "improved" (Housing \& Development Board, 1985). Later, as the housing crisis eased, other models were introduced but overall the number of varieties remained very limited. For example, there are only 14 model varieties in the nearly 170,000 resale transactions during our sample period, 2000 to 2005. Standardization of units and limited variety means that HDB apartments are well-described by the number of rooms and the flat model, both observed in our dataset. Accordingly, unobservable differences in quality are much less than in other housing markets.

HDB apartment buildings are located in 26 carefully planned satellite towns throughout Singapore. Each town has its own town center, commercial and retail space, and educational, health care, and recreational facilities. As the planning and development of the earliest established towns are completed, and the population of Singapore increases $!^{5}$ new HDB towns are founded and developed incrementally (Housing \& Development Board, 1985). The former towns, typically at least 20 years of age, are categorized by HDB as "mature." The latter, still expanding towns are referred to as "non-mature." Mature towns have better amenities, and, as a result, apartments in these towns tend to be more expensive. Amenities of non-mature towns are improving over time as their populations grow, with the addition of traditional Singaporean food centers, called hawker centres, supermarkets, community facilities, etc., which positively affect housing prices. Therefore, housing prices in mature and non-mature towns likely follow different time trends. In our study, we will focus on HDB apartments located in these mature towns, where the supply of HDB

\footnotetext{
${ }^{5}$ The population of Singapore has increased significantly since independence in 1965, with a population of $1,886,900$, to a 2015 population of $5,535,002$. During our sample period, population increased by $6 \%$ from 4,027,887 in 2000 to 4,265,762 in 2005 (Singapore Department of Statistics, 2015).
} 
housing was very stable during our sample period ${ }^{6}$ For instance, there were 464,135 HDB apartments in mature towns in 2000 and 461,902 in 2005.7 By focusing on these towns, our results are unlikely to be driven by either improving amenities or supply shocks.

New HDB apartments are sold only to Singaporean citizens, under restrictive terms and conditions, and the price is heavily discounted. As many as 13 different schemes provide additional subsidies, including the "Additional CPF Housing Grant" and the "Special CPF Housing Grant," which each provide up to $\$ \$ 40,000$ in subsidies to eligible buyers. Along with these subsidies comes restrictions such as an income ceiling. Currently, for example, a family must have average gross monthly income of $\$ \$ 12,000$ or less to be eligible to buy a new HDB apartment.

In contrast, the market that we consider, the resale market for HDB apartments, is largely unrestricted and competitive. It is also very active. From 2000 to 2015, over 436,000 resale transactions took place, which is more than 27,000 annually ( $3 \%$ of the total stock of HBD apartments in 2015). The main restrictions on resale transactions are (1) buyers must be a Singaporean citizen or permanent resident; and (2) owners can only sell their apartments after a Minimum Occupancy Period, between 1 to 2.5 years in our sample period..$^{8}$

Given its small size and growing population, the Singapore government has long recognized the need for policies that encourage commuters to take public transportation. It does so by investing in a rail and bus system with affordable fares 99 and by making owning

\footnotetext{
${ }^{6}$ These mature towns include Ang Mo Kio, Bedok, Bishan, Bukit Merah, Bukit Timah, Central, Clementi, Geylang, Kallang Whampoa, Marine Parade, Pasir Ris, Queenstown, Serangoon, Tampines, and Toa Payoh.

${ }^{7}$ The decline in the number of apartments is likely due to demolition of older buildings. The number of apartments in non-mature towns increased 14.7\%, from 364,013 in 2000 to 417,664 in 2005. (Housing \& Development Board, various years)

${ }^{8}$ Exceptions are sometimes made, for example, if the household suffers a medical crisis or death and selling the apartment is a financial necessity.

${ }^{9}$ For example, in 2003, the average MRT fare per trip was about a quarter of the average London fare
} 
and operating a car extremely costly. The car ownership rate of HDB residents was a low $31 \%$ in 2004, and people took the MRT for $19 \%$ of their trips. This percentage increases to $27 \%$ for people of households that did not own a vehicle.

Singapore policy discourages car use in several ways. To own a car one must have a Certificate of Entitlement (COE), which provides the right to own a car for 10 years. COEs are limited by a quota and allocated by auction. The average COE auctioned for about $\mathrm{S} \$ 31,000$ in 2002 , the year before the expansion, and $\mathrm{S} \$ 25,000$ in 2004 , the year after 10 Gasoline taxes are high, about 50 cents a liter ( $\$ \$ 1.90$ per gallon), the road tax can be upwards of $\$ \$ 2,000$ annually, and drivers in heavily trafficked areas pay tolls collected under the Electronic Road Pricing system 11

Investment in the public railway system, called the Mass Rapid Transit (MRT), has similarly encouraged high public transportation usage. The idea of constructing a rail system in Singapore was first raised in 1967, though actual construction did not commence until October 1983. Initially, the MRT consisted of two segments, the North South Line and the East West Line, with $67 \mathrm{~km}$ of track and 42 stations. Construction finished two years ahead of schedule with the last station opening July 1990. The North South Line was extended by an additional $16 \mathrm{~km}$ of track and 6 stations in February 1996. Between 1996 and 2003, only three more stations were opened, one in January 2001, one in October 2001, and one in February 2002.

The second major expansion of the MRT, and the one this paper focuses on, occurred in June 2003 with the opening of the North East Line and its $20 \mathrm{~km}$ of track and its initial and half of the average New York City fare. Moreover, the average MRT fare per trip did not increase over the sample period. (Singapore Land Transit Authority, various years)

${ }^{10}$ Cars are very expensive to buy as well. A new, mid-sized sedan such as a Toyota Camry can cost around $\mathrm{S} \$ 90,000$.

${ }^{11}$ See Ho et al. (2014) for further details on the Certificate of Entitlement system and Singapore car policies. 
14 of 16 stations. Plans for the North East Line were approved by the government in January 1996 with a scheduled completion date at the end of 2002. In September 2002 it was announced that the opening would be delayed to as late as April 2003. After several more delays, the North East Line was finally opened in June 2003. Another station opened in January 2006, and the line was completed when the last station opened in June 2011.

In February 2009 the East West Line was further extended by $3.8 \mathrm{~km}$ with two additional stations. In May 2009, part of the fourth line, the Circle Line, became operational with the opening of five stations. The Circle Line was completed with 11 stations and 11.1 $\mathrm{km}$ added in April 2010, 12 stations and $16 \mathrm{~km}$ added in 2011, and the final two stations and $2.4 \mathrm{~km}$ added in 2012. Currently, the $42 \mathrm{~km}$ Downtown Line and its 34 stations are under construction and are scheduled to be completed sometime in 2017.

In this paper, we focus on the impact of the 2003 North East Line opening on housing prices for several reasons: (1) The North East Line was a major expansion, increasing the number of MRT stations by $27 \%$ and the rail length by $22 \%$; (2) There were no major additions to the MRT system within five and half years of the 2003 extension, which precludes any confounding effects of further expansions and allows the market to converge to a new equilibrium price; (3) Unlike the later extensions, all 14 new stations of the North East Line were opened in the same month, which provides a well defined threshold for our before and after analysis.

Panel (a) of Figure 1 maps the mature and non-mature HDB towns and the three MRT lines as of 2003. The East West Line and the North South Line have been in service since 1990, and the North East Line opened in June 2003. One can see that the mature HDB towns, that is, the oldest and completely developed towns, are nearest to the Central Business District (CBD). As the population of Singapore increases, towns are established further into the "suburbs" of Singapore. These towns are still being developed 
with amenities and new housing being added over time. Panel (b) maps the three MRT lines and all HDB buildings with at least 25 resale transactions in the sample period. The figure shows that the MRT lines were designed to connect HDB towns. As a result, most HDB apartments are located within $3 \mathrm{~km}$ of an MRT station. Panel (c) of Figure 1 shows the location of HDB buildings in mature towns and within $1.5 \mathrm{~km}$ of an MRT station on either the East West Line or the North South Line. Resale transactions of apartments in these buildings are included in several specifications below.

\subsection{Data}

This study uses housing transaction data downloaded from the Singapore government's data portal: www.data.gov.sg. The data contains the universe of HDB resale transactions since January 2000 and includes transaction price, transaction date, street address including a 6 digit zip code, floor number in intervals, unit area, number of rooms, apartment model, and year of construction.

We use all transactions that took place between 2000 and the third quarter of 2005, 2 years after the 2003 MRT expansion. In all, our sample includes 22 quarters: 13 quarters before the North East Line opened, the quarter in which it opened, and 8 quarters after. The long pre-expansion period helps to identify whether the prices of connected and unconnected apartments follow the same time trend before the expansion, which is a crucial support for our identification approach, and we allow the possibility that price adjusts for up to two years after the expansion while minimizing the influence of one new station in 2006 and a larger expansion in 2009 of 8 new stations, whose construction plans were publicly announced at the end of 2004 .

Using Google Maps, we extracted the longitude and latitude of each HDB building that 
contains resale transactions. Then, for each building, we calculated the direct distance to the closest pre-expansion MRT station. While the direct distance only serves as a lower bound for the actual walking distance, the difference between the actual walking distance and the direct distance is likely to be small as HDB communities are open, ungated communities that allow barrier-free passage.

Since we wish to abstract from the effect of being newly or better connected to the MRT system, we exclude transactions in any building in which the distance to the nearest MRT station decreased due to the expansion. Further, transactions in any buildings within 1.5 $\mathrm{km}$ of the new North East Line were also excluded as the values of these apartments might be directly affected by the new line. To get a sense of how the 2003 expansion affected the distribution of distance to the near MRT station, we took all resale transactions in 2002 and computed the distance to the nearest stations before the expansion and distance to the larger set of stations after the expansion. Figures 2 and 3 contains the histograms of these two distance calculations. The histograms show that the expansion reduced the distance to the nearest MRT station primarily via a reduction in the right tail. After the expansion, these 2002 transacted apartments were located within $3.5 \mathrm{~km}$ of an MRT station, $66 \%$ of them were located within $1 \mathrm{~km}$, and $22 \%$ within $0.5 \mathrm{~km}$ of an MRT station.

Table 1 reports descriptive statistics. Our sample consists of 77,240 transactions within $2 \mathrm{~km}$ of a pre-expansion MRT station. Of these transacted apartments, $21 \%$ were within $0.5 \mathrm{~km}$ of a pre-expansion station, $43 \%$ within $0.75 \mathrm{~km}, 62 \%$ within $1 \mathrm{~km}$, and $89 \%$ within $1.5 \mathrm{~km}$. The average distance to the nearest station was $0.89 \mathrm{~km}$. The proximity to an MRT station is used to define an apartment's connection status. We consider an apartment as connected to the MRT system if it is within walking distance. Given the year-long hot and humid tropical climate of Singapore, people are rarely willing to walk a long distance. According to the 2004 Household Interview Travel Survey conducted by the Land Transport 
Authority, the median walking distance to the MRT was $0.19 \mathrm{~km}$ and $82 \%$ of those who walked to the MRT station walked $0.5 \mathrm{~km}$ or less. We use these values as a guide to define "pre-connected" apartments in our main specification as those within $0.5 \mathrm{~km}$ of a preexpansion station. These apartments are compared to "unconnected" apartments within 0.5 and $1.0 \mathrm{~km}$ of a station. To check whether our results are sensitive to the definition of pre-connected and unconnected apartments, we use different radiuses, including defining pre-connected apartments as units within $0.75 \mathrm{~km}$ of a station and unconnected apartments as units up to 1.5 and to $2 \mathrm{~km}$ away from a station. We also use continuous distance in one specification as a further robustness check.

The average distance to the Central Business District (CBD) was about $10 \mathrm{~km}$ (the Raffles Place MRT station in the CBD is used as the reference point). The average apartment price in January 2000 Singapore dollars was $\$ \$ 245,270$ (US\$180,000), with the lowest price around $\mathrm{S} \$ 53,000$ (US\$39,000) and the highest a little over $\mathrm{S} \$ 700,000$ (US\$514,000). Average age was about 18 years, implying that, under the 99 year lease attached to HDB apartments, there were 71 lease years remaining at the time of transaction 12 Pre-connected apartments are about three years older than unconnected apartments. The fraction of units on the $9^{\text {th }}$ floor or lower is $71 \%$, and the fraction of units with 4 rooms or fewer is $76 \%$. (In the regression analysis below, we user a finer categorization of these variables.)

Table 2 reports several key housing characteristics by connection status and transaction period. The mean price per square meter of pre-connected apartments in the pre-expansion period was $\mathrm{S} \$ 123.62$ higher than that of unconnected apartments. Post expansion, this difference increased to $\mathrm{S} \$ 169.42$. In other words, an apartment close to a pre-expansion

\footnotetext{
${ }^{12}$ As a former British colony, Singapore follows the British leasehold system in which land is either freehold, i.e., owned in perpetuity, or leased from a freeholder for a certain number of years. HDB apartments are sold with a 99 year lease at the end of which the ownership of the apartment reverts to HDB. For further details on the leasehold system in Singapore, readers may refer to Fesselmeyer, Liu, and Salvo (2016).
} 
MRT station appreciated $\mathrm{S} \$ 45.81$ per square meter relative to an apartment farther away, or about $1.7 \%$ of the average price per square meter of the sample, $\mathrm{S} \$ 2,620.08$. We will see below that this estimate is very similar to regression estimates of the impact of the expansion when including a full set of controls.

One sees in Table 2 that there was relatively little difference between the observed characteristics of pre-connected and unconnected apartments, and the changes in the differences in characteristics from the pre-expansion to the post-expansion period were small both economically and statistically. This indicates that there is no selection on observables, which suggests that selection on unobservables is likely to be negligible. The mean difference between pre-connected and unconnected apartments in distance to the CBD was about $1 \mathrm{~km}$ before and after expansion. Pre-connected apartments were 1.5 years older than unconnected apartments in the pre-expansion period; this increased to 1.8 years after expansion. The difference between pre-connected and unconnected apartments in average unit size was about 3.55 square meters, both before and after expansion. The difference in the fraction of units on the $9^{\text {th }}$ floor or lower across periods, 0.02 and 0.01 , and the change over time, -0.01, were very small. Similarly, the difference in the fraction of units with 4 rooms or fewer was small and very similar over time: 0.01 in the pre-expansion period, 0.02 after, and the difference over time was 0.01 .

\section{Model}

In this section, we introduce a simple model of behavior and discuss our estimation approach. Assume that the utility from owning an apartment is

$$
u=U(X, C),
$$


where $X$ is aggregate quality of all housing characteristics except $C$, which represents the benefits of the transit system. For simplicity, we normalize the price of $X$ to 1 . Assume that $C=f(d, n)$, where $d$ is the distance to the nearest station and $n$ is the number of places connected to the transit system. It is reasonable to assume that $\partial f / \partial d \leq 0$ and $\partial f / \partial n \geq 0$. Namely, the benefits provided by the transit system decreases with the distance to the nearest station and increases with coverage. It is also reasonable to assume that $\partial^{2} f / \partial d^{2}>0$. That is, since the likelihood of using the MRT decreases as the distance to the station increases, the impact of $d$ on accessibility decreases with $d$.

An individual (or household) chooses $d$ and $X$ to maximize utility subject to the budget constraint $Y=X+p(d, n) f(d, n)$, where $Y$ is income and price $p(d, n)$ depends on distance to the nearest station and the number of places connected to the system. The first-order conditions imply that an individual's marginal willingness to pay (MWTP) for an apartment located $d \mathrm{~km}$ from the nearest station of a transit system connected to $n$ locations is

$$
p(d, n)=\frac{\partial U / \partial f(d, n)}{\partial U / \partial(Y-p(d, n) f(d, n))} .
$$

Clearly, $p$ decreases with the distance to the nearest station, $d$, and increases with the coverage of the railway network, $n$.

To recover the MWTP for $C$, previous studies estimate:

$$
\ln p_{i}=X_{i} \beta+d_{i} \gamma+\epsilon_{i}
$$

where $p_{i}$ is the price of unit $i$ and $X_{i}$ is a vector of observed characteristics, such as unit size, floor number, and local amenities, such as quality of local schools. The major challenge in identifying the impact of $d_{i}$ on price is that the locations of stations are not randomly 
determined, that is, $\operatorname{cov}\left(d_{i}, \epsilon_{i}\right) \neq 0$. For instance, stations are typically constructed in high density areas in which housing is more expensive. Moreover, a new station often is accompanied by new shops and offices. As a result, the OLS estimate, $\hat{\gamma}$, can be driven either by accessibility to the transit system or by the shopping and jobs around the station. The simultaneity in station openings and shops and offices makes it hard, if not impossible, to identify the direct impact of public transportation on housing prices by measuring how price changed after a station opened.

In this paper, we identify the impact of public transportation on housing prices via the improvement in network coverage, $n$, caused by the expansion of the transit system. Presumably, the expansion had limited impact on amenities in areas surrounding existing stations. Moreover, focusing on mature, built up towns further helps minimize the likelihood that new shops and offices were built around these already connected stations. Nevertheless, an expansion could still affect housing prices via its impact on housing supply, a critique raised by Molloy and Shan (2013) in the literature measuring the impact of gasoline prices on house prices. If HDB constructs more apartments in affected areas in expectation of increased demand, the increase in housing supply will mitigate the expansion price effect. Again, by focusing on mature towns this channel should be minimized as there was little change in housing supply during our sample period. It should be noted however that even though housing supply in these mature areas was stable, the total number of apartments near an MRT station city wide increased as the result of the new North East Line, which reduces the price premium for apartments close to MRT stations. Hence, our estimates can serve as a lower bound.

To illustrate our identification strategy, we assume that there are only two types of apartments: pre-connected and unconnected. If the value of pre-connected apartments depends on the network coverage, the expansion of the network will raise the valuation of 
the former but not the latter. Therefore, the latter can be used as the control group while the former is the treatment group, where the treatment is the opening of the North East Line. In particular, let the price of an apartment be

$$
\ln p_{i t}=\beta_{0}+X_{i t}^{\prime} \beta_{1}+\beta_{2} T_{i t}+\gamma_{t} S_{i}+\phi S_{i} \times E_{i t}+\epsilon_{i t}
$$

where $S=1$ if apartment $i$ is connected to the MRT system and 0 otherwise, $T_{i t}$ is a time dummy that equals one if the transaction was made in period $t$ and 0 otherwise, and $E_{i t}=1$ if the transaction was in the post expansion period and 0 otherwise. Because we focus on apartments whose distance to a station (both pre- and post-expansion) was not affected by the expansion, the variable $S$ does not have a time subscript.

Given the findings of the large body of literature on announcement effects (Waud, 1970; Jud and Winkler, 2006; Grimes and Young, 2013), simply estimating the pre- and post-expansion difference might be too arbitrary. Because people foresee that that the pre-connected apartments will become more attractive because of the new MRT line and apartments are very long-lived assets whose price depends on the discounted sum of future utilities, prices should start to appreciate even before the opening. In our sensitivity analysis, we replace the interaction between $S$ and $E$ with a series of interactions between $S$ and $T$. By doing so, the price differences between the connected and unconnected apartments can change freely over time.

To identify the impact of the MRT expansion on prices, we need two key assumptions: (1) the valuation of the pre-connected and unconnected apartments would follow the same time trend if there was no expansion, and (2) changes in unobserved quality are not correlated with an apartment's connection status.

Although the first assumption is not testable since the counterfactual of no expansion 
is not observable, finding similar trends before expansion provides supportive evidence. Figure 4 graphs average natural log of deflated price per square meter by connection status. The pre-connected apartments are those located within $0.5 \mathrm{~km}$ of a station, while the unconnected apartments are located between 0.5 and $1.0 \mathrm{~km}$ of a station. These somewhat arbitrary choices are checked for robustness in our empirical analysis below.

These price trends follow a very similar pattern from the beginning of 2000 to around four or five quarters before the expansion, with the average price of pre-connected apartments about $4 \%$ higher than unconnected apartments. Thereafter prices diverged as presumably the benefits of the network expansion was capitalized into the price of preconnected apartments, and the price premium remained higher for the rest of the sample period.

The second assumption implies

$$
\begin{aligned}
& {\left[E\left(\epsilon_{i t} \mid E_{i t}=1, S_{i}=1, T_{i t}\right)-E\left(\epsilon_{i t} \mid E_{i t}=0, S_{i}=1, T_{i t}\right)\right] } \\
= & {\left[E\left(\epsilon_{i t} \mid E_{i t}=1, S_{i}=0, T_{i t}\right)-E\left(\epsilon_{i t} \mid E_{i t}=0, S_{i}=0, T_{i t}\right)\right] . }
\end{aligned}
$$

While it is possible that HDB might adjust the quality of their new projects after the expansion to cater to buyers with a higher valuation of the distance to a MRT station, distance does not change once the construction has completed. Since the stock of HDB apartments hardly changed during our sample period, with apartments already built years before the expansion, changes in building quality should not be an issue. However, even though equation (5) might hold for the entire housing stock, it might not be valid among resale units as these apartments were self-selected. For instance, households with stronger preferences for connected apartments might also have stronger preferences for other housing characteristics. If the preference for the observed and unobserved characteristics are 
correlated, and the preference for these characteristics are indeed correlated with the preference for an apartment's connection status, then the estimate of $\phi$ in equation (4) should be sensitive to whether we control for the observed characteristics, $X$. We find, in fact, that our estimate is not affected by the inclusion of $X$. The robustness of our results suggest that even if the expansion of the MRT indeed changed the composition of resale apartments, which does not seem to be the case given the analysis in Table 2 , these changes were likely to be similar for the pre-connected and unconnected units.

\section{Estimation results}

Table 3 reports the estimation results using the natural log of deflated price per square meter as the dependent variable. For columns (1) to (5), we define a treatment ring of "pre-connected" apartments and a control ring of "unconnected" apartments, with the categorization depending on the distance to the nearest pre-expansion MRT station. For

example, in column (1), the treatment ring includes all apartments within $0.5 \mathrm{~km}$ of a pre-expansion MRT station, and the control ring includes all apartments from 0.5 to 1.0 $\mathrm{km}$ of a pre-expansion station.

In the first regression in column (1), we control only for an apartment's connection status, a post-expansion dummy, and their interaction. The coefficient on the interaction is 0.022 ( $\mathrm{SD}=0.008)$, suggesting that the expansion increased the price premium of preconnected apartments by $2.2 \%$. If the only difference between the pre-connected and unconnected apartments, on average, is their connection status, then adding other housing characteristics should not affect our estimate. To check whether this is indeed the case, we control for a set of housing characteristics that are commonly included in hedonic regressions. Specifically, in columns (2) to (5), we include a quadratic function of distance 
to the CBD, of age, and of the size of the apartment, number of rooms fixed effects, flat model fixed effects, floor bin fixed effects, 2-digit zip code fixed effects, and transaction quarter fixed effects ${ }^{13}$ Adding these controls raised the $\mathrm{R}^{2}$ from 0.02 to 0.682 (column (2)), indicating that these characteristics have considerable explanatory power. However, the coefficient on the interaction term only declines slightly to $0.019(\mathrm{SD}=0.006)$ while the standard error of the estimate shrinks by a quarter. The similarity between these two estimates suggest that pre-connected and unconnected apartments are indeed comparable, which is consistent with the homogeneity of HDB apartments in general.

To check whether our results are sensitive to how we define the treatment and control rings, we expand the control ring to $0.5-1.5 \mathrm{~km}$ in column (3), the treatment ring to 0$0.75 \mathrm{~km}$ in column (4), and the treatment and control ring to $0-0.75 \mathrm{~km}$ and $0.75-2.0$ $\mathrm{km}$, respectively, in column (5). Overall, the results are similar across the different ring definitions, and the direction of any differences in the estimates is consistent with the explanation that the impact of the MRT expansion decreases in the distance to a preexpansion MRT station. That is, apartments further from a pre-expansion MRT station benefited less from the expansion than closer apartments.

Expanding the control ring in column (3) increases the impact of the estimate to 0.021 $(\mathrm{SD}=0.006)$ as the average impact within the larger control ring decreases relative to the treatment group, increasing the estimate. Enlarging the treatment ring from 0.5 to 0.75 $\mathrm{km}$ in column (4), but keeping the control ring at $1.5 \mathrm{~km}$, has little impact on the estimate. Enlarging the treatment ring shifts apartments from 0.5 to $0.75 \mathrm{~km}$, whose benefit from the expansion is less than apartments nearer the MRT, into the newly defined treatment group,

\footnotetext{
${ }^{13}$ Each building in Singapore is assigned a unique 6 digit zip code. In our main specifications, we control for location by grouping buildings by the first two digits of the building's zip code, which introduces 53 location fixed effects. In a robustness check, we control for location more finely by grouping buildings by the first four digits, which introduces 465 location fixed effects.
} 
which reduces the average impact within it. But the benefit of these same apartments is greater than the benefit of those farther away from an MRT station, which decreases the average impact in the new control group as well. The decline in the estimate implies that the former effect dominates. The point estimate increases to 0.021 in column (5), where the control ring is between 0.75 and $2.0 \mathrm{~km}$, because of the addition of apartments 1.5 to $2 \mathrm{~km}$ from a MRT station, which were not likely affected much by the expansion. In column (6), we replace discrete rings with continuous distance in $\mathrm{km}$ to the nearest preexpansion MRT station. We limit this subsample to include apartments within $2 \mathrm{~km}$ of a pre-expansion station. The coefficient on the interaction between the post-expansion dummy and the distance to the nearest MRT station is $-0.035(\mathrm{SD}=0.006)$, i.e., the value of apartments located at $0.25 \mathrm{~km}$ from the nearest station increased by $1.75 \%$ relative to similar apartments located $0.75 \mathrm{~km}$ from the nearest MRT station, which is nearly identical to the estimate in column (2).

Table A.1 in the Appendix repeats the analysis of Table 3 using finer location fixed effects by grouping buildings by the first 4 digits of the zip code. The estimates are very similar to those in Table 3. Table A.2 replaces the dependent variable with deflated price per square meter in levels. The results remain very robust: the price of a pre-connected apartment is estimated to have increased between $\mathrm{S} \$ 30$ and $\mathrm{S} \$ 46$ per square meter due to the MRT expansion and all results are significant at the $5 \%$ level. Using continuous distance, we find that an apartment near a pre-expansion station appreciated by about $\mathrm{S} \$ 76$ after the expansion relative to an apartment $1 \mathrm{~km}$ away.

One implicit assumption that we make by using the interaction of an apartment's proximity to an MRT station with a post-expansion dummy is that the expansion only affected prices from the time that the North East Line opened. However, given the findings of a large literature on announcement effects mentioned in the previous section, price may 
have begun adjusting before the North East Line opened. To check, we allow a more flexible specification by interacting the treatment ring dummy with the transaction quarter dummies. The dependent variable is natural log of price per square meter and the control variables are identical to those used in the ring regressions in Table 3. The treatment ring extends to $0.5 \mathrm{~km}$ and the control ring from 0.5 to $1.0 \mathrm{~km}$. Coefficient estimates of the ring and quarter interactions and 95\% confidence intervals are plotted in Figure 5 and listed in Table 4. All estimates are significant at the $1 \%$ level. The difference in the price of apartments in the treatment ring and the control ring increased from $2 \%$ at the beginning of the sample to $3.7 \%$ nine quarters before the expansion quarter. For the next four quarters, this difference was similar except for a temporary increase six quarters before expansion. About a year before the planned opening, price began to appreciate sharply in the treatment ring. By the actual, delayed opening evidently the benefits of the network expansion had been fully capitalized as the price premium of an apartment close to a station reached around $5.8 \%$ three quarters before the expansion, and remained stable for nearly three years thereafter, a period in which there was no further MRT expansions.

To get a better sense of the magnitude of the estimated price effect, note that the $1.9 \%$ estimate in column (2) of Table 3 implies an increase of about $\mathrm{S} \$ 4,660$ at the average price in the sample. We can use a simple discounting model to convert this figure into an annual benefit.

Consider a model in which the transaction price of an apartment is equal to the sum of discounted annual utility over the lifetime of the apartment, $T$ years. Let $u$ be the constant, annual utility in real dollars provided by an apartment near a pre-expansion MRT station before the expansion, and $r$ be the real discount rate. Then, the price of this 
unit is determined by:

$$
p=\left(1+\sum_{t=2}^{T}\left(\frac{1}{1+r}\right)^{t}\right) u
$$

Let the utility derived from a similar unit transacted after the expansion be $u^{\prime}$ and let its price be $p^{\prime}$. Then, the difference in prices can be written as:

$$
p^{\prime}-p=\left(1+\sum_{t=2}^{T}\left(\frac{1}{1+r}\right)^{t}\right)\left(u^{\prime}-u\right) .
$$

We have estimated $p^{\prime}-p$ to be around $\mathrm{S} \$ 4,660$. To determine a reasonable value for T, consider, as mentioned previously, that HDB apartments are sold with 99-year leases, at the end of which they return to HDB. Since the average age in the sample is around 18 years, the average remaining lease years is about 71 years, which we will take to be the value of $T$. Finally, for $r$ we use the 2.1\% estimated by Fesselmeyer, Liu, and Salvo (2016) with Singapore housing data. Using these values, from equation (7), we estimate $u^{\prime}-u$ to be about $\mathrm{S} \$ 124$ per year. That is, in real terms, we estimate that the annual utility of living in a already connected apartment increased by about $\mathrm{S} \$ 124$ due to the expansion of the MRT network.

\section{Heterogeneous Effects}

In the next three subsections, we consider whether the valuation of the MRT expansion differs by subsample. In particular, we measure whether the effect of the MRT expansion on price differs by car ownership rates, family size (proxied by flat size), and income (proxied by floor). We find that our estimated effects vary in reasonable ways, providing further robustness to our primary results. 


\subsection{Car ownership}

As explained previously, due mostly to government regulation that aims to push commuters to use public transportation, owning and operating a car in Singapore is very expensive and the overall ownership rate, particularly among HDB households, is low. As such, one would expect the value of the MRT expansion to differ across households with and without cars. Ideally, this would be tested using household level data on car ownership and housing prices, but this data is unavailable. Instead, we test for heterogeneous effects by estimating whether areas with low car ownership rates valued the expansion more than in areas with high car ownership rates ${ }^{14}$

To do so we divided our sample into two subsamples. The low car ownership sample contains all transactions of apartments in two-digit zip code locations with car ownership rates below the median rate of 0.3 . The second subsample contains the remaining transactions in two-digit zip code locations with car ownership rates of 0.3 or greater. We then estimated our preferred model, with a treatment ring to $0.5 \mathrm{~km}$ and a control ring from 0.5 to $1 \mathrm{~km}$, and a complete set of control variables, on each subsample. The results are reported in Table 5 .

Column (1) contains the results for the subsample below the median car ownership rate, and column (2) above. The coefficient estimate on the treatment ring-post expansion interaction is 0.016 and significant at the $5 \%$ level $(\mathrm{p}$-value $=0.022)$ for the subsample with low car ownership rates. The estimate for the high car ownership group is half the size, 0.008, and not statistically different than zero. In words, households near a preexpansion MRT station in areas with low car ownership rates value the expansion of the MRT network. Those households near a pre-expansion MRT stations in areas with high

\footnotetext{
${ }^{14}$ Car ownership rates were computed using data from the 2004 Household Interview Travel Survey.
} 
car ownership rates did not value the expansion any differently than households located further away. These results provide evidence that the MRT expansion was valued by the households most likely to benefit from it, namely those households that were least likely to own cars and that were living in apartments near a pre-expansion MRT station.

\section{$5.2 \quad$ Number of rooms}

In this subsection, we consider whether family size affects the valuation of the MRT expansion. We expect larger families to value an expansion more since there are more family members to enjoy the benefits. Since we do not observe family size directly, we proxy family size by the number of rooms in the apartment because, in general, a larger family requires more living space. In particular, we split the sample into two subsamples based on the median number of rooms, and run separate regressions.

The results of the regression using the subsample of small apartments of three rooms or fewer are reported in column (3) of Table 5, and those using the subsample of large apartments of four rooms or more are in column (4). The effect of the MRT expansion estimated using small apartments is close to zero and not statistically significant. The effect for large apartments is twice as big and statistically significant at the $1 \%$ level. This difference suggests that larger families value the MRT expansion more than smaller families do.

\subsection{Floor}

We now consider how income affects the valuation of the MRT expansion. With the high cost of owning and operating a car in Singapore we expect low income families to value the MRT expansion more than high income families. Since we do not observe income we 
proxy for income by using floor number. Because of the tropical climate, to avoid bugs and to enjoy the breeze Singaporeans prefer living on high floors, and these units cost much more than units on lower floors. For example, the highest apartments, on the $28^{\text {th }}$ to $30^{\text {th }}$ floors, sold for $56 \%$ more than apartments on the $3^{\text {rd }}$ floor or lower. Presumably then people living on higher floors have higher incomes. Again, we split the sample into two subsamples based on the median floor, and run separate regressions.

The results of a regression using the subsample of apartments on the $6^{\text {th }}$ floor or lower is contained in column (5) of Table 5, and those using the subsample of apartments on the $7^{\text {th }}$ floor or higher are in column (6). The effect of the MRT expansion on the low floor apartments subsample is twice as large as in the high floor apartments subsample, $2.6 \%$ to $1.3 \%$, with both estimates being statistically significant. That is, lower income families value the increased access via the MRT twice as much as higher income families.

\section{Conclusion}

In this paper, we measure the impact on housing prices of the opening of the North East Line, a major expansion of Singapore's commuter rail system that added 14 stations and increased rail length by over $20 \%$. In contrast to the approach of the existing literature which focuses on housing whose proximity to the transit network is affected by an expansion, we measure the change in housing prices in areas that were already connected, which provides cleaner identification of the benefits of the expansion. We also contribute to the literature on network effects by measuring the benefit of a network expansion to early adopters of the network in a context that has not been considered before.

We find that the North East Line increased the prices of already connected apartments by $1.6 \%$ to $2.1 \%$. When evaluated at the mean housing price of $\mathrm{S} \$ 245,270$ (about 
US\$180,000), the expansion increased the value of pre-connected apartments by at least S\$386 million, which is equivalent to about $8 \%$ of the estimated $\mathrm{S} \$ 5$ billion cost of the expansion. This suggests that the magnitude of network externalities is substantial in comparison to construction cost, which is consistent with the findings of Gowrisankaran and Stavins (2004). The presence of such sizable externalities indicates that the benefits to households living in already connected apartments should be included in cost-benefit analyses evaluating investments in public transit systems. 


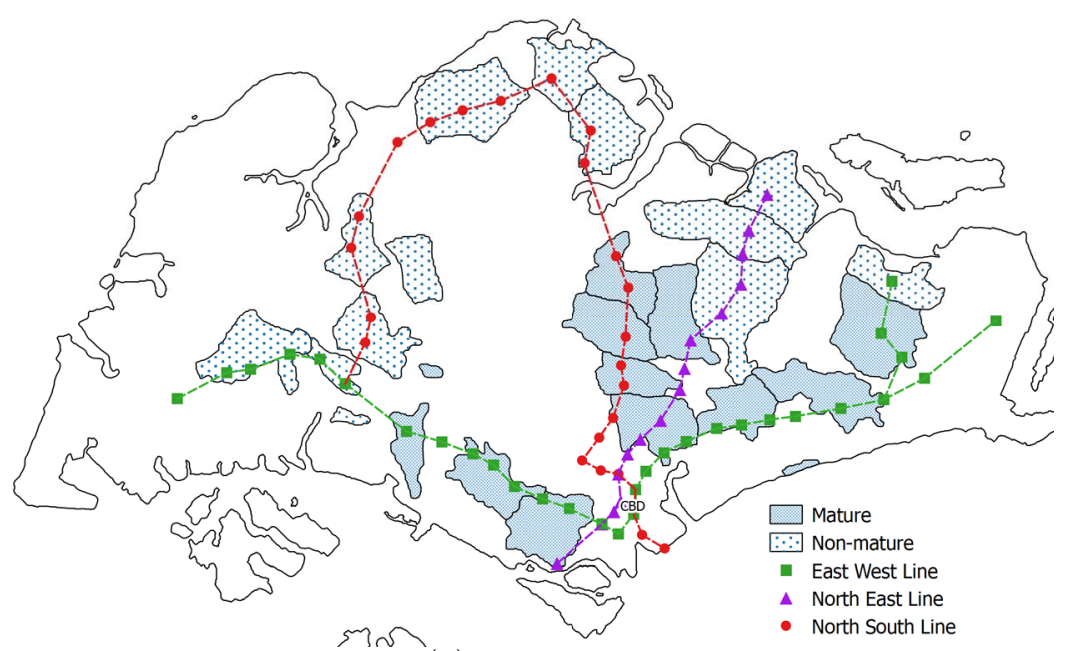

(a) HDB Towns

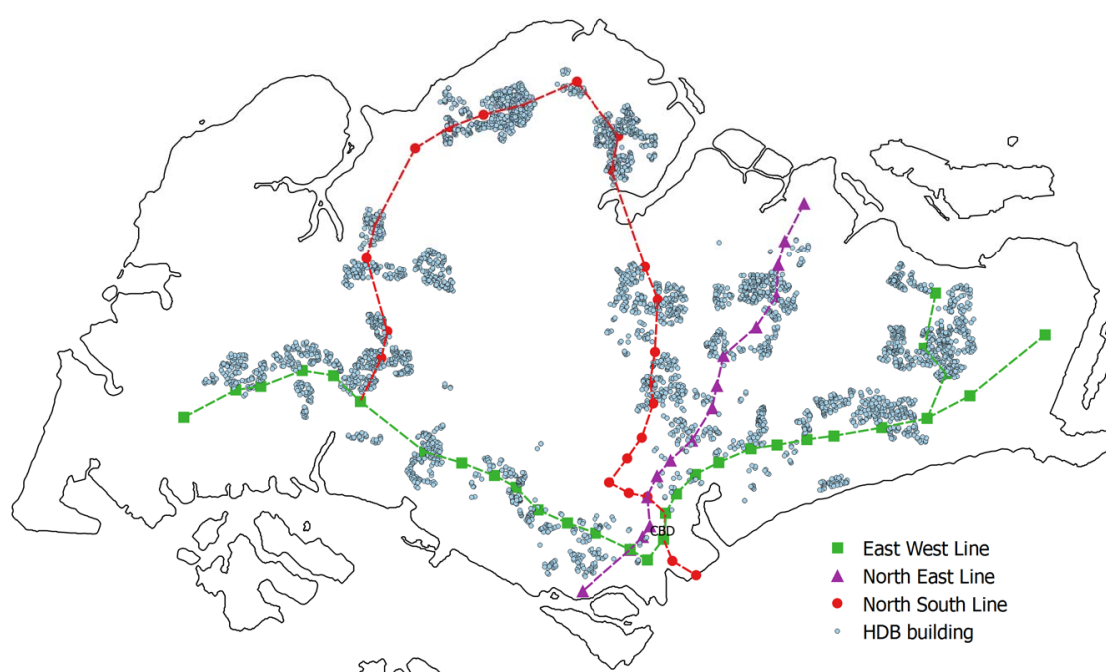

(b) HDB buildings with more than 25 sales

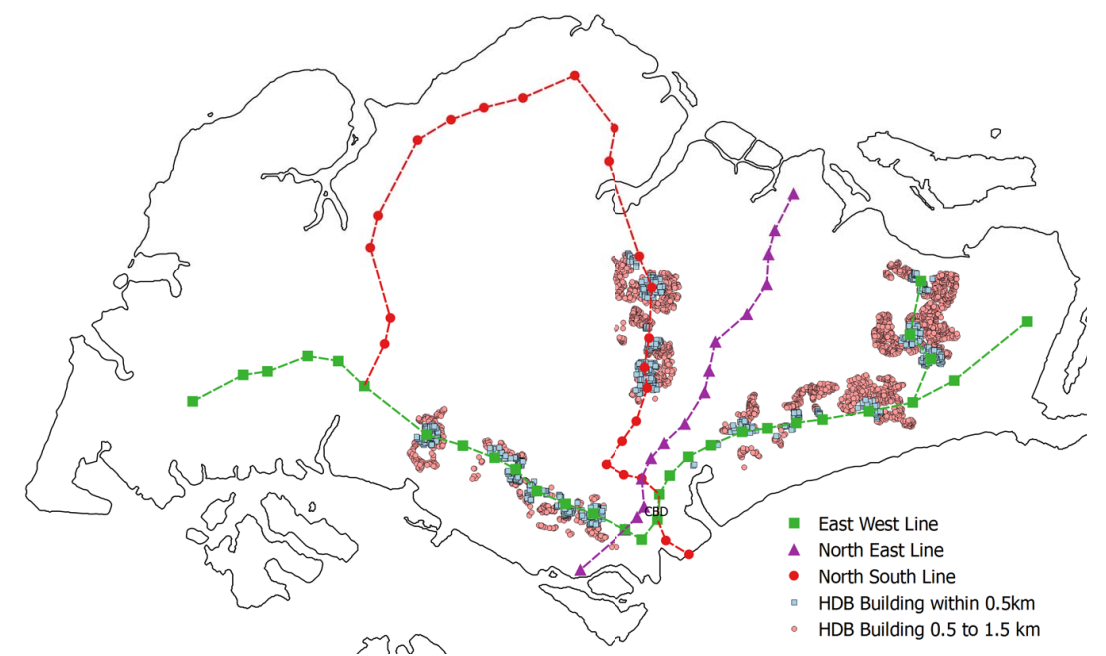

(c) HDB buildings in mature towns within $1.5 \mathrm{~km}$ of an existing MRT station

Figure 1: Maps 


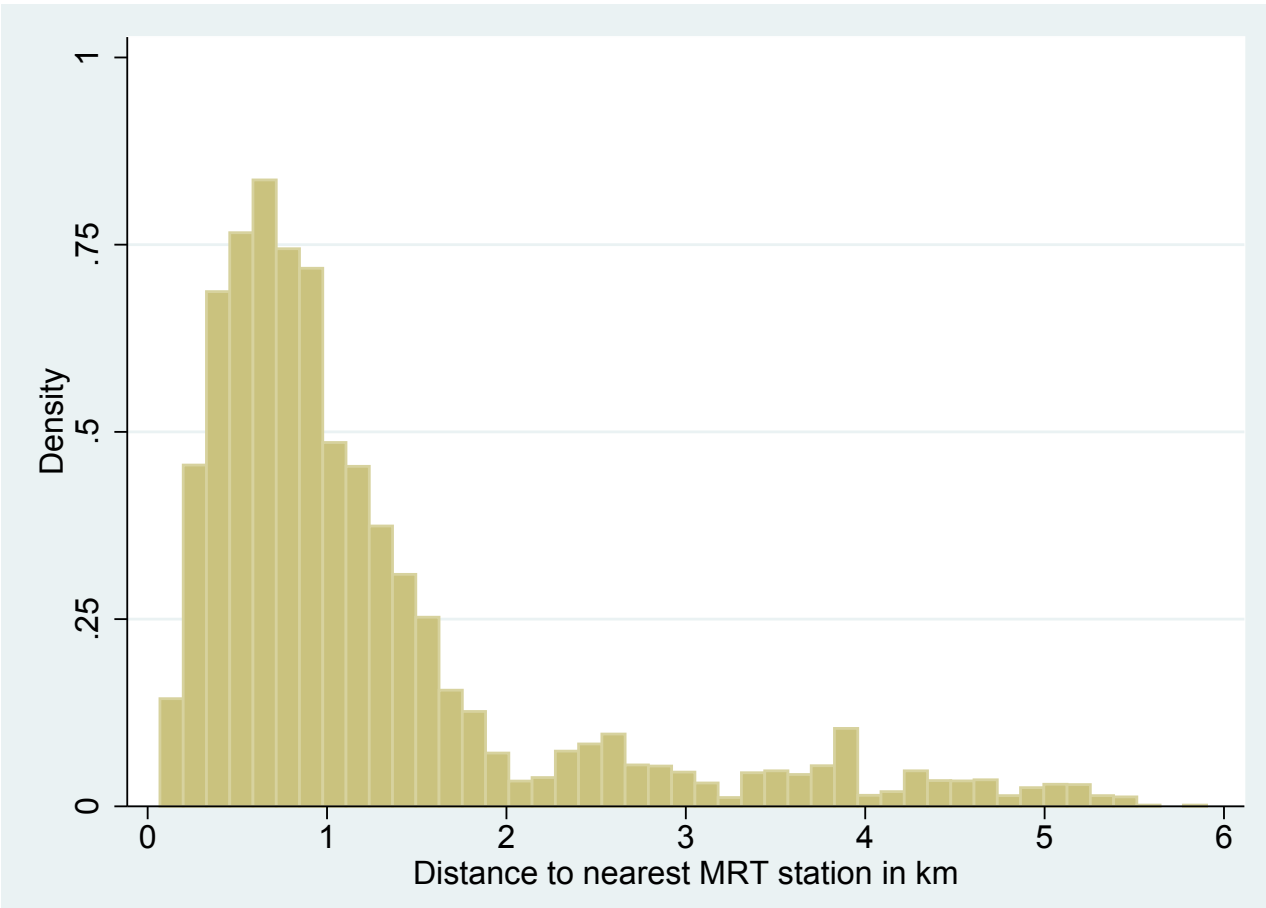

Figure 2: Distance to MRT, 2002 transactions, using set of stations before 2003 expansion

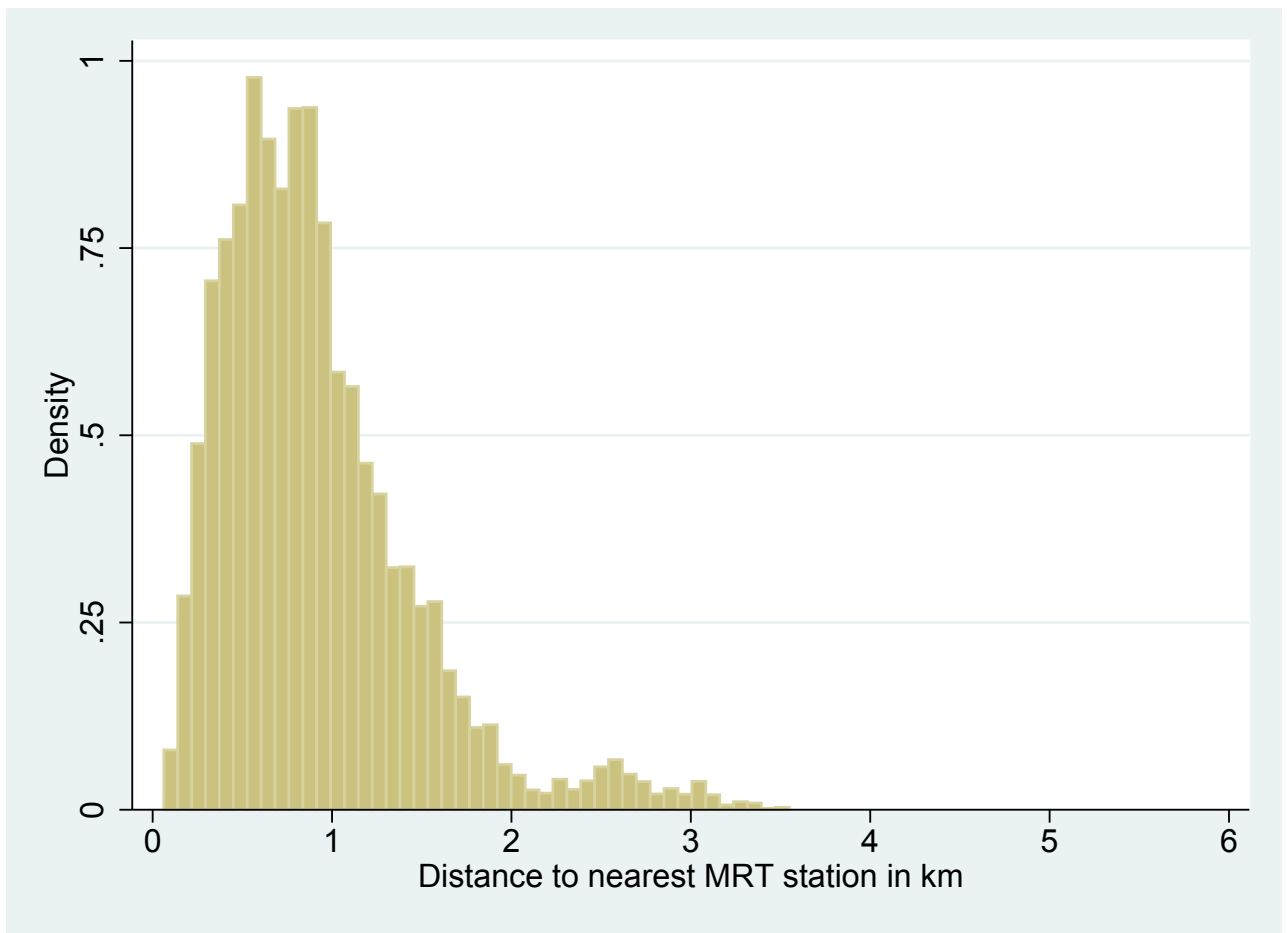

Figure 3: Distance to MRT, 2002 transactions, using set of stations after 2003 expansion 


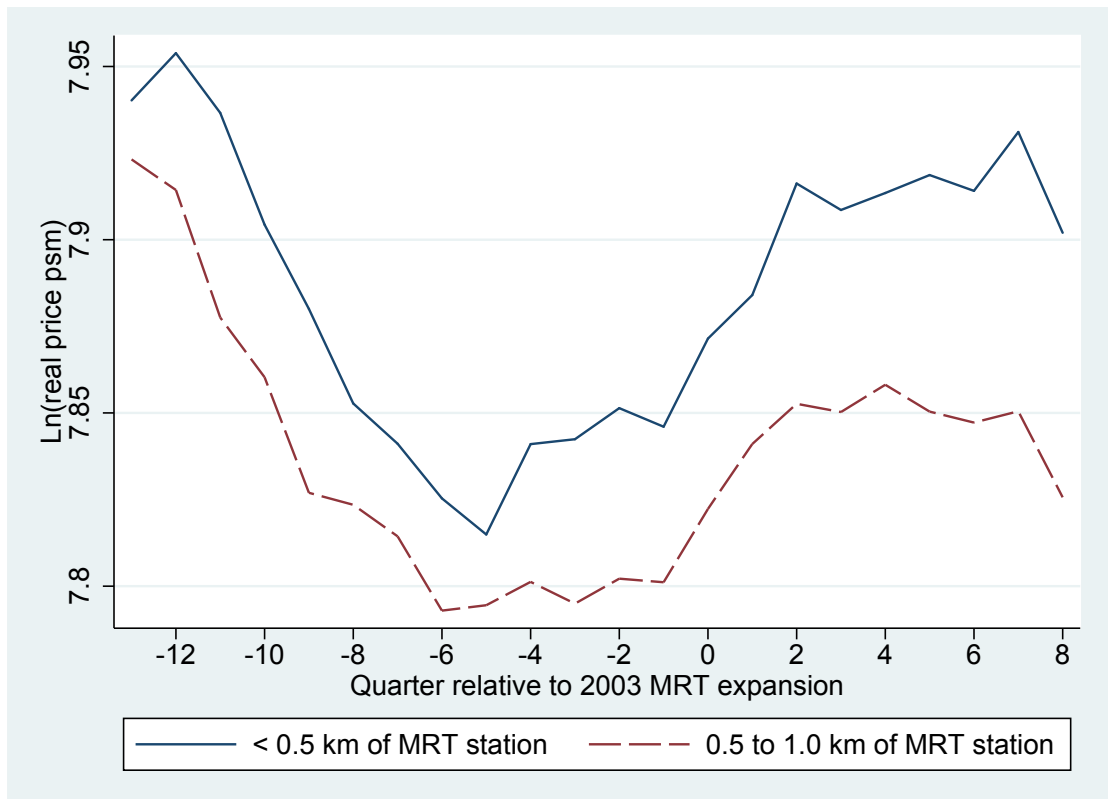

Figure 4: Ln(real price psm) by distance to MRT groups

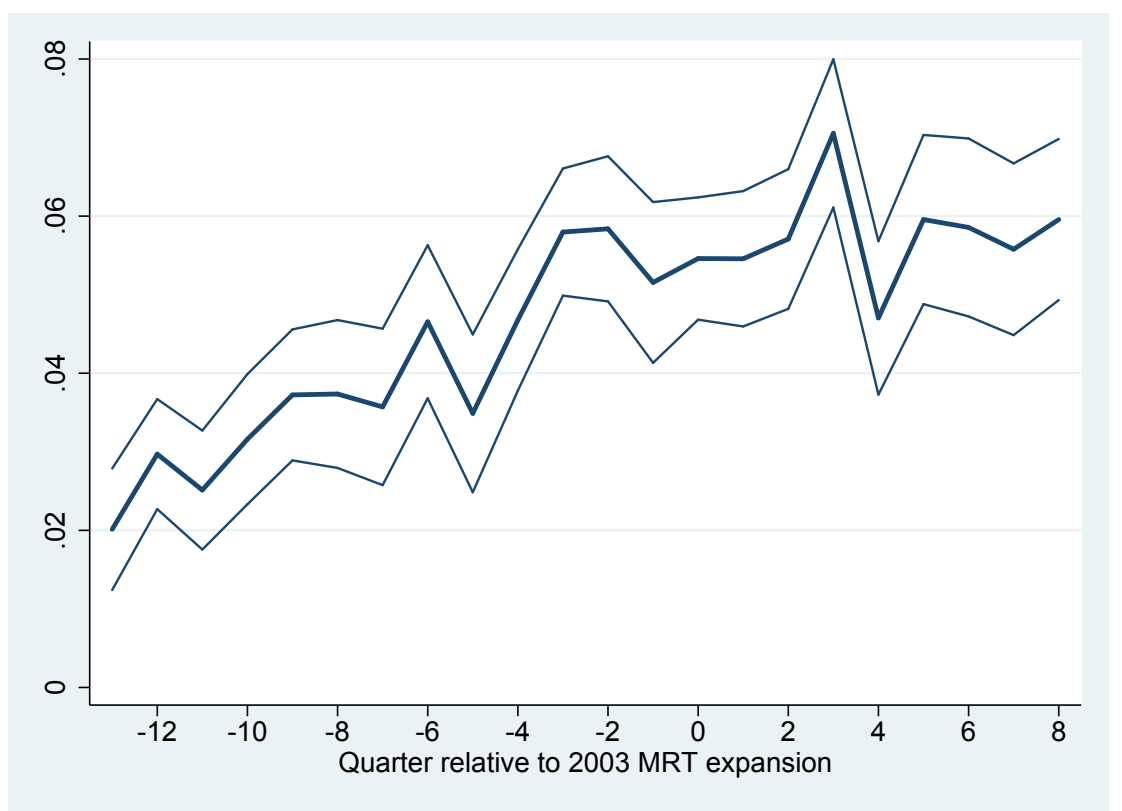

Figure 5: "Pre-connected" coefficient estimates and 95\% CI by quarter, rings: 0.5 and 1.0. Dependent variable: natural log of price per square meter. 
Table 1: Summary Statistics

\begin{tabular}{lcccc}
\hline VARIABLES & Mean & StDev & Min & Max \\
\hline Price in January 2000 S\$ & 245,270 & 102,325 & 53,027 & 728,637 \\
Within 0.5 km & 0.21 & 0.41 & 0.00 & 1.00 \\
Within $0.75 \mathrm{~km}$ & 0.43 & 0.50 & 0.00 & 1.00 \\
Within $1.0 \mathrm{~km}$ & 0.62 & 0.48 & 0.00 & 1.00 \\
Within $1.5 \mathrm{~km}$ & 0.89 & 0.32 & 0.00 & 1.00 \\
Post-expansion period & 0.34 & 0.47 & 0.00 & 1.00 \\
Distance to MRT in km & 0.89 & 0.44 & 0.07 & 2.00 \\
Distance to CBD in km & 9.89 & 3.23 & 2.02 & 15.95 \\
Age in years & 18.36 & 8.52 & 0.00 & 38.00 \\
Unit area in m & 91.99 & 26.68 & 38.00 & 243.00 \\
$9^{\text {th }}$ floor or lower & 0.71 & 0.46 & 0.00 & 1.00 \\
4 rooms or fewer & 0.76 & 0.43 & 0.00 & 1.00 \\
\hline Observations & 77,240 & \multicolumn{4}{l}{} \\
\hline \multicolumn{5}{l}{}
\end{tabular}


Table 2: Means by Connectedness and Period

\begin{tabular}{|c|c|c|c|c|c|c|c|}
\hline \multirow[b]{2}{*}{ VARIABLES } & \multicolumn{3}{|c|}{ Pre-expansion } & \multicolumn{3}{|c|}{ Post-expansion } & \multirow[b]{2}{*}{$\begin{array}{c}(6)-(3) \\
\quad(7)\end{array}$} \\
\hline & $\begin{array}{c}\text { Pre-connected } \\
(1)\end{array}$ & $\begin{array}{c}\text { Unconnected } \\
(2)\end{array}$ & $\begin{array}{c}(2)-(1) \\
(3)\end{array}$ & $\begin{array}{c}\text { Pre-connected } \\
(4)\end{array}$ & $\begin{array}{c}\text { Unconnected } \\
(5)\end{array}$ & $\begin{array}{c}(5)-(4) \\
(6)\end{array}$ & \\
\hline Price per $\mathrm{m}^{2}$ in January $2000 \mathrm{~S} \$$ & $2,692.66$ & $2,569.04$ & 123.62 & $2,746.44$ & $2,577.02$ & 169.42 & 45.80 \\
\hline Distance to $\mathrm{CBD}$ in $\mathrm{km}$ & 8.74 & 9.68 & -0.94 & 8.39 & 9.42 & -1.03 & -0.09 \\
\hline Age in years & 20.05 & 18.57 & 1.48 & 23.75 & 21.95 & 1.8 & 0.32 \\
\hline Unit area in $\mathrm{m}^{2}$ & 86.76 & 90.31 & -3.55 & 83.17 & 86.72 & -3.55 & 0.00 \\
\hline $9^{\text {th }}$ floor or lower & 0.72 & 0.70 & 0.02 & 0.70 & 0.69 & 0.01 & -0.01 \\
\hline 4 rooms or fewer & 0.80 & 0.79 & 0.01 & 0.85 & 0.83 & 0.02 & 0.01 \\
\hline Observations & 10,499 & 20,370 & & 6,003 & 11,165 & & \\
\hline
\end{tabular}


Table 3: Dependent variable: Log deflated price per $\mathrm{m}^{2}$.

\begin{tabular}{|c|c|c|c|c|c|c|}
\hline $\begin{array}{l}\text { Treatment ring: } \\
\text { Control ring: }\end{array}$ & $\begin{array}{c}0 \text { to } 0.5 \\
0.5 \text { to } 1 \\
(1)\end{array}$ & $\begin{array}{c}0 \text { to } 0.5 \\
0.5 \text { to } 1 \\
(2)\end{array}$ & $\begin{array}{c}0 \text { to } 0.5 \\
0.5 \text { to } 1.5 \\
(3)\end{array}$ & $\begin{array}{c}0 \text { to } 0.75 \\
0.75 \text { to } 1.5 \\
(4)\end{array}$ & $\begin{array}{c}0 \text { to } 0.75 \\
0.75 \text { to } 2 \\
(5)\end{array}$ & Continuous \\
\hline Pre-connected & $\begin{array}{c}0.042^{* * *} \\
(0.010)\end{array}$ & $\begin{array}{c}0.038^{* * *} \\
(0.005)\end{array}$ & $\begin{array}{c}0.055^{* * *} \\
(0.005)\end{array}$ & $\begin{array}{c}0.059 * * * \\
(0.004)\end{array}$ & $\begin{array}{c}0.060^{* * *} \\
(0.005)\end{array}$ & \\
\hline Pre-connected $\times$ Post expansion & $\begin{array}{c}0.022^{* * *} \\
(0.008)\end{array}$ & $\begin{array}{c}0.019^{* * *} \\
(0.006)\end{array}$ & $\begin{array}{c}0.021^{* * *} \\
(0.006)\end{array}$ & $\begin{array}{c}0.016^{* * *} \\
(0.005)\end{array}$ & $\begin{array}{c}0.021^{* * *} \\
(0.005)\end{array}$ & \\
\hline Distance to MRT in $\mathrm{km}$ & & & & & & $\begin{array}{c}-0.086^{* * *} \\
(0.006)\end{array}$ \\
\hline Distance to MRT $\times$ Post expansion & & & & & & $\begin{array}{c}-0.035^{* * *} \\
(0.006)\end{array}$ \\
\hline Distance to $\mathrm{CBD}$ in $\mathrm{km}$ & & $\begin{array}{c}-0.100^{* * *} \\
(0.012)\end{array}$ & $\begin{array}{c}-0.072^{* * *} \\
(0.010)\end{array}$ & $\begin{array}{c}-0.072^{* * *} \\
(0.010)\end{array}$ & $\begin{array}{c}-0.063^{* * *} \\
(0.009)\end{array}$ & $\begin{array}{c}-0.063^{* * *} \\
(0.009)\end{array}$ \\
\hline Distance to CBD, squared & & $\begin{array}{c}0.004^{* * *} \\
(0.001)\end{array}$ & $\begin{array}{c}0.003^{* * *} \\
(0.000)\end{array}$ & $\begin{array}{c}0.003^{* * *} \\
(0.000)\end{array}$ & $\begin{array}{c}0.002^{* * *} \\
(0.000)\end{array}$ & $\begin{array}{c}0.002^{* * *} \\
(0.000)\end{array}$ \\
\hline Age in years & & $\begin{array}{c}-0.027^{* * *} \\
(0.002)\end{array}$ & $\begin{array}{c}-0.021^{* * *} \\
(0.002)\end{array}$ & $\begin{array}{c}-0.024^{* * *} \\
(0.002)\end{array}$ & $\begin{array}{c}-0.022^{* * *} \\
(0.002)\end{array}$ & $\begin{array}{c}-0.024^{* * *} \\
(0.002)\end{array}$ \\
\hline Age, squared & & $\begin{array}{c}0.001^{* * *} \\
(0.000)\end{array}$ & $\begin{array}{c}0.000^{* * *} \\
(0.000)\end{array}$ & $\begin{array}{c}0.001^{* * *} \\
(0.000)\end{array}$ & $\begin{array}{c}0.000^{* * *} \\
(0.000)\end{array}$ & $\begin{array}{c}0.001^{* * *} \\
(0.000)\end{array}$ \\
\hline Apartment model fixed effects & No & Yes & Yes & Yes & Yes & Yes \\
\hline Number of rooms fixed effects & No & Yes & Yes & Yes & Yes & Yes \\
\hline Floor bin fixed effects & No & Yes & Yes & Yes & Yes & Yes \\
\hline Unit area quadratic & No & Yes & Yes & Yes & Yes & Yes \\
\hline 2-digit zip code fixed effects & No & Yes & Yes & Yes & Yes & Yes \\
\hline Post-expansion dummy variable & Yes & NA & NA & NA & NA & NA \\
\hline Transaction quarter fixed effects & No & Yes & Yes & Yes & Yes & Yes \\
\hline $\mathrm{R}^{2}$ & 0.020 & 0.682 & 0.648 & 0.654 & 0.662 & 0.670 \\
\hline Observations & 48,037 & 48,037 & 68,523 & 68,523 & 77,240 & 77,240 \\
\hline
\end{tabular}

Notes: ${ }^{* * *} \mathrm{p}<0.01,{ }^{*} \mathrm{p}<0.05, * \mathrm{p}<0.1$. The dependent variable is the logarithm of the apartment's transaction price divided by the size of the unit (in January $2000 \mathrm{~S} \$$ per $\mathrm{m}^{2}$ ). Standard errors, in parentheses, are clustered by block and transaction quarter. Columns differ by the radius of the inner ring and outer ring. 
Table 4: "Pre-connected" coefficient estimates by quarter, Rings: 0.5 and $1.0 \mathrm{~km}$

\begin{tabular}{lcc}
\hline Quarter Relative to Expansion & Coef. & Std. Err. \\
\hline 13 quarters before & 0.020 & 0.004 \\
12 quarters before & 0.030 & 0.004 \\
11 quarters before & 0.025 & 0.004 \\
10 quarters before & 0.032 & 0.004 \\
9 quarters before & 0.037 & 0.004 \\
8 quarters before & 0.037 & 0.005 \\
7 quarters before & 0.036 & 0.005 \\
6 quarters before & 0.047 & 0.005 \\
5 quarters before & 0.035 & 0.005 \\
4 quarters before & 0.047 & 0.005 \\
3 quarters before & 0.058 & 0.004 \\
2 quarters before & 0.058 & 0.005 \\
1 quarter before & 0.052 & 0.005 \\
Quarter of expansion & 0.055 & 0.004 \\
1 quarter after & 0.055 & 0.004 \\
2 quarters after & 0.057 & 0.005 \\
3 quarters after & 0.071 & 0.005 \\
4 quarters after & 0.047 & 0.005 \\
5 quarters after & 0.060 & 0.005 \\
6 quarters after & 0.059 & 0.006 \\
7 quarters after & 0.056 & 0.006 \\
8 quarters after & 0.060 & 0.005 \\
\hline
\end{tabular}

Notes: All estimates are significant at the $1 \%$ level. The dependent variable is the logarithm of the apartment's transaction price divided by the size of the unit (in January $2000 \mathrm{~S} \$$ per $\mathrm{m}^{2}$ ). Standard errors, in parentheses, are clustered by block and transaction quarter. Regression includes apartment model, number of rooms, floor bin, 2-digit zip code, and transaction quarter dummy variables, and a quadratic in age and in unit area. 
Table 5: Dependent variable: Log deflated price per $\mathrm{m}^{2}$.

\begin{tabular}{lcccccc}
\hline & Car ownership & Car ownership & Rooms & Rooms & Floor & Floor \\
& $<30 \%$ & $\geq 30 \%$ & $<4$ & $\geq 4$ & $<7$ & $\geq 7$ \\
& $(1)$ & $(2)$ & $(3)$ & $(4)$ & $(5)$ & $(6)$ \\
\hline Connected & $0.033^{* * *}$ & $0.054^{* * *}$ & $0.042^{* * *}$ & $0.053^{* * *}$ & $0.031^{* * *}$ & $0.045^{* * *}$ \\
& $(0.006)$ & $(0.008)$ & $(0.006)$ & $(0.004)$ & $(0.005)$ & $(0.005)$ \\
Connected $\times$ Post expansion & $0.016^{* *}$ & 0.008 & 0.006 & $0.013^{* * *}$ & $0.026^{* * *}$ & $0.013^{* *}$ \\
& $(0.007)$ & $(0.008)$ & $(0.006)$ & $(0.005)$ & $(0.007)$ & $(0.006)$ \\
Distance to CBD in km & $-0.100^{* * *}$ & $-0.121^{* * *}$ & $-0.120^{* * *}$ & $-0.056^{* * *}$ & $-0.102^{* * *}$ & $-0.097^{* * *}$ \\
& $(0.014)$ & $(0.023)$ & $(0.017)$ & $(0.010)$ & $(0.013)$ & $(0.014)$ \\
Distance to CBD, squared & $0.004^{* * *}$ & $0.005^{* * *}$ & $0.005^{* * *}$ & $0.002^{* * *}$ & $0.004^{* * *}$ & $0.004^{* * *}$ \\
& $(0.001)$ & $(0.001)$ & $(0.001)$ & $(0.000)$ & $(0.001)$ & $(0.001)$ \\
Age in years & $-0.025^{* * *}$ & $-0.043^{* * *}$ & $-0.019^{* * *}$ & $-0.022^{* * *}$ & $-0.028^{* * *}$ & $-0.026^{* * *}$ \\
& $(0.002)$ & $(0.004)$ & $(0.004)$ & $(0.002)$ & $(0.003)$ & $(0.002)$ \\
Age, squared & $0.001^{* * *}$ & $0.001^{* * *}$ & $0.000^{* * *}$ & $0.000^{* * *}$ & $0.001^{* * *}$ & $0.001^{* * *}$ \\
& $(0.000)$ & $(0.000)$ & $(0.000)$ & $(0.000)$ & $(0.000)$ & $(0.000)$ \\
& & & & & & \\
Apartment model fixed effects & Yes & Yes & Yes & Yes & Yes & Yes \\
Number of rooms fixed effects & Yes & Yes & Yes & Yes & Yes & Yes \\
Floor number fixed effects & Yes & Yes & Yes & Yes & Yes & Yes \\
Unit area quadratic & Yes & Yes & Yes & Yes & Yes & Yes \\
2-digit zip code fixed effects & Yes & Yes & Yes & Yes & Yes & Yes \\
Transaction quarter fixed effects & Yes & Yes & Yes & Yes & Yes & Yes \\
\hline $\mathrm{R}^{2}$ & 0.655 & 0.768 & 0.791 & 0.928 & 0.626 & 0.714 \\
Observations & 31,804 & 16,233 & 24,245 & 23,792 & 21,820 & 26,217 \\
\hline
\end{tabular}

Notes: ${ }^{* * *} \mathrm{p}<0.01,{ }^{* *} \mathrm{p}<0.05,{ }^{*} \mathrm{p}<0.1$. Standard errors, in parentheses, are clustered by block and quarter. The dependent variable is the property's transaction price divided by the size of the unit (in January $2000 \mathrm{~S} \$$ per $\mathrm{m}^{2}$ ). Regressions include floor, flat type, flat model, and 2-digit zip code dummy variables, and a quadratic in unit area. 
Table A.1: Dependent variable: Log deflated price per $\mathrm{m}^{2}$.

\begin{tabular}{|c|c|c|c|c|c|c|}
\hline Treatment ring: & 0 to 0.5 & 0 to 0.5 & 0 to 0.5 & 0 to 0.75 & 0 to 0.75 & Continuous \\
\hline Control ring: & $\begin{array}{c}0.5 \text { to } 1 \\
(1)\end{array}$ & $\begin{array}{c}0.5 \text { to } 1 \\
(2)\end{array}$ & $\begin{array}{c}0.5 \text { to } 1.5 \\
(3)\end{array}$ & $\begin{array}{c}0.75 \text { to } 1.5 \\
\text { (4) }\end{array}$ & $\begin{array}{c}0.75 \text { to } 2 \\
(5)\end{array}$ & $(6)$ \\
\hline Pre-connected & $\begin{array}{c}0.042^{* * *} \\
(0.010)\end{array}$ & $\begin{array}{c}0.028^{* * *} \\
(0.005)\end{array}$ & $\begin{array}{c}0.027^{* * *} \\
(0.005)\end{array}$ & $\begin{array}{c}0.033^{* * *} \\
(0.005)\end{array}$ & $\begin{array}{c}0.031^{* * *} \\
(0.005)\end{array}$ & \\
\hline Pre-connected $\times$ Post expansion & $\begin{array}{c}0.022^{* * *} \\
(0.008)\end{array}$ & $\begin{array}{c}0.019^{* * *} \\
(0.006)\end{array}$ & $\begin{array}{c}0.020^{* * *} \\
(0.006)\end{array}$ & $\begin{array}{c}0.014^{* *} \\
(0.006)\end{array}$ & $\begin{array}{c}0.020^{* * *} \\
(0.005)\end{array}$ & \\
\hline Distance to MRT in $\mathrm{km}$ & & & & & & $\begin{array}{c}-0.064^{* * *} \\
(0.008)\end{array}$ \\
\hline Distance to MRT $\times$ Post expansion & & & & & & $\begin{array}{c}-0.032^{* * *} \\
(0.006)\end{array}$ \\
\hline Distance to CBD in $\mathrm{km}$ & & $\begin{array}{c}-0.097^{* * *} \\
(0.017)\end{array}$ & $\begin{array}{c}-0.067^{* * *} \\
(0.016)\end{array}$ & $\begin{array}{c}-0.080^{* * *} \\
(0.016)\end{array}$ & $\begin{array}{c}-0.082^{* * *} \\
(0.015)\end{array}$ & $\begin{array}{c}-0.086^{* * *} \\
(0.015)\end{array}$ \\
\hline Distance to CBD, squared & & $\begin{array}{c}0.005^{* * *} \\
(0.001)\end{array}$ & $\begin{array}{c}0.003^{* * *} \\
(0.001)\end{array}$ & $\begin{array}{c}0.004^{* * *} \\
(0.001)\end{array}$ & $\begin{array}{c}0.004^{* * *} \\
(0.001)\end{array}$ & $\begin{array}{c}0.004^{* * *} \\
(0.001)\end{array}$ \\
\hline Age in years & & $\begin{array}{c}-0.032^{* * *} \\
(0.002)\end{array}$ & $\begin{array}{c}-0.033^{* * *} \\
(0.003)\end{array}$ & $\begin{array}{c}-0.034^{* * *} \\
(0.003)\end{array}$ & $\begin{array}{c}-0.032^{* * *} \\
(0.003)\end{array}$ & $\begin{array}{c}-0.032^{* * *} \\
(0.003)\end{array}$ \\
\hline Age, squared & & $\begin{array}{c}0.001^{* * *} \\
(0.000)\end{array}$ & $\begin{array}{c}0.001^{* * *} \\
(0.000)\end{array}$ & $\begin{array}{c}0.001^{* * *} \\
(0.000)\end{array}$ & $\begin{array}{c}0.001^{* * *} \\
(0.000)\end{array}$ & $\begin{array}{c}0.001^{* * *} \\
(0.000)\end{array}$ \\
\hline Apartment model fixed effects & No & Yes & Yes & Yes & Yes & Yes \\
\hline Number of rooms fixed effects & No & Yes & Yes & Yes & Yes & Yes \\
\hline Floor bin fixed effects & No & Yes & Yes & Yes & Yes & Yes \\
\hline Unit area quadratic & No & Yes & Yes & Yes & Yes & Yes \\
\hline 4-digit zip code fixed effects & No & Yes & Yes & Yes & Yes & Yes \\
\hline Post expansion dummy variable & Yes & NA & NA & NA & NA & NA \\
\hline Transaction quarter fixed effects & No & Yes & Yes & Yes & Yes & Yes \\
\hline $\mathrm{R}^{2}$ & 0.020 & 0.710 & 0.692 & 0.692 & 0.697 & 0.701 \\
\hline Observations & 48,037 & 48,037 & 68,523 & 68,523 & 77,240 & 77,240 \\
\hline
\end{tabular}

Notes: ${ }^{* * *} \mathrm{p}<0.01,{ }^{* *} \mathrm{p}<0.05,{ }^{*} \mathrm{p}<0.1$. Standard errors, in parentheses, are clustered by block and quarter. The dependent variable is the property's transaction price divided by the size of the unit (in January $2000 \mathrm{~S} \$$ per $\mathrm{m}^{2}$ ). Columns differ by the radius of the inner circle and outer circle. 
Table A.2: Dependent variable: Deflated price per $\mathrm{m}^{2}$.

\begin{tabular}{|c|c|c|c|c|c|c|}
\hline $\begin{array}{l}\text { Treatment ring: } \\
\text { Control ring: }\end{array}$ & $\begin{array}{l}0 \text { to } 0.5 \\
0.5 \text { to } 1 \\
(1)\end{array}$ & $\begin{array}{c}0 \text { to } 0.5 \\
0.5 \text { to } 1 \\
(2)\end{array}$ & $\begin{array}{c}0 \text { to } 0.5 \\
0.5 \text { to } 1.5 \\
(3)\end{array}$ & $\begin{array}{c}0 \text { to } 0.75 \\
0.75 \text { to } 1.5 \\
(4)\end{array}$ & $\begin{array}{c}0 \text { to } 0.75 \\
0.75 \text { to } 2 \\
(5)\end{array}$ & Continuous \\
\hline Pre-connected & $\begin{array}{c}123.624^{* * *} \\
(27.873)\end{array}$ & $\begin{array}{c}106.397^{* * * *} \\
(12.138)\end{array}$ & $\begin{array}{c}155.090^{* * *} \\
(12.606)\end{array}$ & $\begin{array}{c}162.070^{* * *} \\
(10.352)\end{array}$ & $\begin{array}{c}166.810^{* * *} \\
(11.228)\end{array}$ & \\
\hline Pre-connected $\times$ Post expansion & $\begin{array}{l}45.800^{* *} \\
(22.949)\end{array}$ & $\begin{array}{c}38.301^{* * *} \\
(14.492)\end{array}$ & $\begin{array}{c}41.153^{* * *} \\
(14.438)\end{array}$ & $\begin{array}{c}30.369^{* *} \\
(12.860)\end{array}$ & $\begin{array}{c}43.663^{* * *} \\
(12.468)\end{array}$ & \\
\hline Distance to MRT in $\mathrm{km}$ & & & & & & $\begin{array}{c}-241.607^{* * * *} \\
(14.465)\end{array}$ \\
\hline Distance to MRT $\times$ Post expansion & & & & & & $\begin{array}{c}-75.908^{* * *} \\
(15.132)\end{array}$ \\
\hline Distance to CBD in $\mathrm{km}$ & & $\begin{array}{c}-277.293^{* * *} \\
(33.424)\end{array}$ & $\begin{array}{c}-198.866^{* * *} \\
(28.571)\end{array}$ & $\begin{array}{c}-199.655^{* * *} \\
(28.413)\end{array}$ & $\begin{array}{c}-177.981^{* * *} \\
(25.762)\end{array}$ & $\begin{array}{c}-178.164^{* * * *} \\
(24.367)\end{array}$ \\
\hline Distance to CBD, squared & & $\begin{array}{c}11.107^{* * *} \\
(1.571)\end{array}$ & $\begin{array}{c}7.026^{* * *} \\
(1.218)\end{array}$ & $\begin{array}{c}7.116^{* * *} \\
(1.212)\end{array}$ & $\begin{array}{c}5.811^{* * * *} \\
(1.072)\end{array}$ & $\begin{array}{c}5.901 * * * \\
(0.989)\end{array}$ \\
\hline Age in years & & $\begin{array}{c}-78.641^{* * *} \\
(4.821)\end{array}$ & $\begin{array}{c}-60.111^{* * *} \\
(6.210)\end{array}$ & $\begin{array}{c}-66.455^{* * *} \\
(5.731)\end{array}$ & $\begin{array}{c}-61.181^{* * *} \\
(5.635)\end{array}$ & $\begin{array}{c}-66.534^{* * *} \\
(5.200)\end{array}$ \\
\hline Age, squared & & $\begin{array}{c}1.600^{* * *} \\
(0.135)\end{array}$ & $\begin{array}{c}1.212^{* * *} \\
(0.178)\end{array}$ & $\begin{array}{c}1.367^{* * *} \\
(0.164)\end{array}$ & $\begin{array}{c}1.245^{* * *} \\
(0.165)\end{array}$ & $\begin{array}{c}1.355^{* * *} \\
(0.155)\end{array}$ \\
\hline Apartment model fixed effects & No & Yes & Yes & Yes & Yes & Yes \\
\hline Number of rooms fixed effects & No & Yes & Yes & Yes & Yes & Yes \\
\hline Floor bin fixed effects & No & Yes & Yes & Yes & Yes & Yes \\
\hline Unit area quadratic & No & Yes & Yes & Yes & Yes & Yes \\
\hline 2-digit zip code fixed effects & No & Yes & Yes & Yes & Yes & Yes \\
\hline Post expansion dummy variable & Yes & NA & NA & NA & NA & NA \\
\hline Transaction quarter fixed effects & No & Yes & Yes & Yes & Yes & Yes \\
\hline $\mathrm{R}^{2}$ & 0.020 & 0.713 & 0.674 & 0.680 & 0.685 & 0.694 \\
\hline Observations & 48,037 & 48,037 & 68,523 & 68,523 & 77,240 & 77,240 \\
\hline
\end{tabular}

Notes: ${ }^{* * *} \mathrm{p}<0.01,{ }^{* *} \mathrm{p}<0.05,{ }^{*} \mathrm{p}<0.1$. The dependent variable is the the apartment's transaction price divided by the size of the unit (in January $2000 \mathrm{~S} \$$ per $\mathrm{m}^{2}$ ). Standard errors, in parentheses, are clustered by block and transaction quarter. Columns differ by the radius of the inner ring and outer ring. 


\section{References}

Bajari, P., Fruehwirth, J. C., Kim, K. i., and Timmins, C. (2012). A rational expectations approach to hedonic price regressions with time-varying unobserved product attributes: The price of pollution. American Economic Review, 102(5):pp. 1898-1926.

Baum-Snow, N. and Kahn, M. E. (2000). The effects of new public projects to expand urban rail transit. Journal of Public Economics, 77(2):241-263.

Black, D., Kolesnikova, N., and Taylor, L. (2014). Why do so few women work in New York (and so many in Minneapolis)? labor supply of married women across U.S. cities. Journal of Urban Economics, 79:59-71.

Bowes, D. R. and Ihlanfeldt, K. R. (2001). Identifying the impacts of rail transit stations on residential property values. Journal of Urban Economics, 50(1):1-25.

Brynjolfsson, E. and Kemerer, C. F. (1996). Network externalities in microcomputer software: An econometric analysis of the spreadsheet market. Management Science, 42(12):1627-1647.

Dewees, D. N. (1976). The effect of a subway on residential property values in Toronto. Journal of Urban Economics, 3(4):357-369.

Fesselmeyer, E., Liu, H., and Salvo, A. (2016). How do households discount over centuries? Evidence from Singapore's private housing market. working paper.

Gandal, N. (1994). Hedonic price indexes for spreadsheets and an empirical test for network externalities. RAND Journal of Economics, 25(1):160-170.

Gibbons, S. and Machin, S. (2005). Valuing rail access using transport innovations. Journal of Urban Economics, 57(1):148-169.

Gowrisankaran, G. and Stavins, J. (2004). Network externalities and technology adoption: Lessons from electronic payments. RAND Journal of Economics, 35(2):260-276. 
Greenstone, M. and Gallagher, J. (2008). Does hazardous waste matter? evidence from the housing market and the superfund program. Quarterly Journal of Economics, 123(3):951-1003.

Grimes, A. and Young, C. (2013). Spatial effects of urban rail upgrades. Journal of Transport Geography, 30:1-6.

Ho, T.-H., Png, I. P. L., and Reza, S. (2015). Sunk Cost Fallacy in Driving the World's Costliest Cars. working paper.

Housing \& Development Board (various years). Annual Report. Housing \& Development Board.

Housing \& Development Board (1985). Wong, A. K., and Yeh, S. H. K., editors, Housing a Nation: 25 Years of Public Housing in Singapore. Maruzen Asia.

Jackson, C. K. and Owens, E. G. (2011). One for the road: public transportation, alcohol consumption, and intoxicated driving. Journal of Public Economics, 95(1):106-121.

Jud, G. D. and Winkler, D. T. (2006). The announcement effect of an airport expansion on housing prices. Journal of Real Estate Finance and Economics, 33(2):91-103.

Katz, M. L. and Shapiro, C. (1985). Network externalities, competition, and compatibility. American Economic Review, 75(3):424-440.

Leong, C.T. (1996, February). North-East MRT: Recommendation to Cabinet by year end. The Straits Times.

Liebowitz, S. J. and Margolis, S. E. (1994). Network externality: An uncommon tragedy. Journal of Economic Perspectives, 8(2):133-150.

McDonald, J. F. and Osuji, C. I. (1995). The effect of anticipated transportation improvement on residential land values. Regional Science and Urban Economics, 25(3):261-278. 
McMillen, D. P. and McDonald, J. (2004). Reaction of house prices to a new rapid transit line: Chicago's midway line, 1983-1999. Real Estate Economics, 32(3):463-486.

Molloy, R. and Shan, H. (2013). The effect of gasoline prices on household location. Review of Economics and Statistics, 95(4):1212-1221.

Nelson, L. J. (2015, November). Costs and delays mount for downtown L.A. subway link. The Los Angeles Times.

Saloner, G. and Shepard, A. (1995). Adoption of technologies with network effects: An empirical examination of the adoption of automated teller machines. RAND Journal of Economics, 26(3):479-501.

Singapore Department of Statistics. (2015). Singapore in Figures. Singapore Department of Statistics.

Singapore Land Transit Authority (various years). Singapore Land Transport Statistics in Brief. Singapore Land Transit Authority.

Voith, R. (1991). Transportation, sorting and house values. Real Estate Economics, 19(2):117-137.

Waud, R. N. (1970). Public interpretation of federal reserve discount rate changes: Evidence on the "announcement effect". Econometrica, 38(2):231-250.

Yueng, Y.M. (1973). National Development Policy and Urban Transformation in Singapore: A Study of Public Housing and the Marketing System. The University of Chicago, Department of Geography, Research Paper 149. 